\title{
Heavy Metals Contents and Histopathological Analysis of Some Organs of Fish from Payau River, Kutai Kartanegara, Indonesia
}

\author{
SULISTYAWATI ${ }^{1}$, IWAN SUYATNA ${ }^{2}$, AHMAD RAFI' ${ }^{3}$, AND GHITARINA ${ }^{4} *$ \\ ${ }^{1)}$ Laboratory of Aquatic Toxicology, Faculty of Fisheries and Marine Science. Mulawarman University, \\ Indonesia \\ ${ }^{2)}$ Laboratory of Kartohydro-Oceanografi, Faculty of Fisheries and Marine Science, Mulawarman \\ University, Indonesia \\ ${ }^{3)}$ Department of Water Resources Management, Faculty of Fisheries and Marine Science Mulawarman \\ University, Indonesia \\ 4) Laboratory of Water Quality, Faculty of Fisheries and Marine Science. Mulawarman University, \\ Indonesia
}

\begin{abstract}
The objectives of this study were to determine the heavy metals contents $(\mathrm{Cd}, \mathrm{Pb}, \mathrm{Cu}$, and $\mathrm{Zn})$ in some freshwater fish and to examine the histopathological changes of the fish organs. The fishes were obtained from Payau River in Anggana, Kutai Kartanegara District, East Kalimantan, Indonesia. There were four species examined namely: Glass Fish (Chanda sp), Croaker (Micropogenias undulatus), Lais (Kryptopterus cryptopterus), and spotted catfish (Arius maculatus). Lead $(\mathrm{Pb})$, Cadmium $(\mathrm{Cd})$, Copper $(\mathrm{Cu})$, and $\mathrm{Zinc}(\mathrm{Zn})$ were analyzed in the gills, livers, and the muscles of the fish. The results showed that $\mathrm{Pb}$ and $\mathrm{Cd}$ were still low and fulfilled the quality standards by Indonesian National Standards Agency and Directorate of Drug and Food Control No. 03725/B/SK/VII/89. Cadmium concentration in the fish organ was $<0.003 \mathrm{mg} \mathrm{kg}^{-1}$ (maximum limit is $0.1 \mathrm{mg} \mathrm{kg}^{-1}$ ) and $\mathrm{Pb}$ concentration was $<0.002 \mathrm{mg} \mathrm{kg}^{-1}$ (quality standard is $0.3 \mathrm{mg} \mathrm{kg}^{-1}$ ). Yet, $\mathrm{Cu}$ and $\mathrm{Zn}$ concentrations were exceeded the quality standard as the levels were $2.63-2.93 \mathrm{mg} \mathrm{kg}^{-1}$ and $60.23-65.55 \mathrm{mg} \mathrm{kg}^{-1}$, respectively. Based on histopathological analysis of the gills, livers, and muscles, the fish experienced edema, hyperplasia, vacuolar degenerative, necrosis, and hemorrhagic.
\end{abstract}

Keywords: freshwater fish, heavy metals, histopathology, Payau River

\section{INTRODUCTION}

Payau River is part of Mahakam Delta waters that is in Anggana, Kutai Kartanegara District, East Kalimantan. This region had been recognized as important potential freshwater fish and supply for the market in Samarinda and around. In addition, Payau River is also used for transportation including coal transportation using pontoon in which could damage the aquatic environment and decrease the productivity of the waters.

Fish is commonly used as biomarker for aquatic pollution by evaluating the

Correspondence Author: Ghitarina: Laboratory of Water Quality, Faculty of Fisheries and Marine Science. Mulawarman University, Indonesia; Tel. +6281253893760; Email: ghitarina@fpik.unmul.ac.id. physiological aspect (Kock et al., 1996) or other aspects (Authman, 2015). Since fish live in water, some of histological structure are quite different compared to land animal. As stated by Takashima and Hibiya (1995), the tissues of fish are sometime different from those other animals and humans.

In aquatic environment, a chemical contaminant enters the body of the organisms by direct or indirect absorption through the membrane layer of the tissue. The contaminant enters the autotroph organism tissues by direct absorption in which the contaminant crosses the biology barrier that separate internal medium organism from external environmental by epithelium of gills (Boudou et al., 1983). 
Heavy metals, for example, may enter and accumulate in the fish organ through the gills, the skin, or through their food chain (Authman, 2015). Based on study conducted by Suyatna et al., (2014), Pb, $\mathrm{Cd}, \mathrm{Cu}$, and $\mathrm{Zn}$ were detected in the body of fish obtained from Payau River and Muara Pantuan, in various concentrations and mostly exceeded the standard regulated by the government.

The existence of this condition was the base of this research by focusing on the Anggana (Payau River) to replicate monitoring the content of heavy metal in the body of fish, and so, to analysis tissues damage from an important organ of the fishes was caught on the same located. Gill chosen because the gill of fish is the first target from pollutant in the water, liver is an important organ to metabolism and excretion of xenobiotic compound with several morphological changes based on toxic conditions in the environment (Rocha \& Monteiro, 1999), and muscles is an important part of human consumption, consequently the toxic substances will accumulate in the tissues of the human body.

This research was aimed to analyze the content of $\mathrm{Cd}, \mathrm{Pb}, \mathrm{Cu}$ and $\mathrm{Zn}$ which accumulate in the body of fish from Payau River, and to determine the level of tissues damage (gills, livers and muscles) of the fish.

\section{MATERIALS AND METHODS}

\section{Materials and Location}

Some materials used for analysis were: Bouin fixative, $96 \%$ alcohol, aquades, Paraffin, Hematoxylin and Eosin staining agents, xylol, albumin and Canada balsam.
The tools used include fishing gear in the form of fishing vessels and mini trawls, sample bottles, dissecting sets, ovens, hot plates, Olympus type CX 23 microscopes, microtomes, beaker glass, staining jar.

Sampling was conducted in Payau River located in Anggana District, Kutai Kartanegara Regency. Heavy metal analysis was carried out in the Water Quality Laboratory of the Faculty of Fisheries and Marine Sciences Unmul and Histopathological Analysis conducted at the Laboratory of Aquatic Toxicology, Faculty of Fisheries and Sciences.

\section{Methods}

Surface water and fish were sampled for heavy metals contents and histopathological analysis. As many as four species were examined, namely: Glass Fish (Chanda sp), Croaker (Micropogenias undulates), Lais (Kryptopterus cryptopterus) and spotted catfish (Arius maculatus). Prior determination of the metal's levels, the fish were destructed based on BSNI (2009), then analyzed using Atomic Absorption Spectrophotometry (AAS). The results were compared with Quality Standard from Directorate Food and Drug Control number 03725/B/SK/VII/89, and BSNI 7387 (2009).

The tissues (Gills, livers, and muscles) of the fish were collected and prepared for serial sectioning in relation to histopathological analysis. The specimens were processed using standard histological techniques based on Sonia Mumford (2007) with dehydrated through a graded series of ethanol, cleared with xylene, embedded with melted paraffin. Section of 5-6 $\mu \mathrm{m}$ thickness were cut by rotary 
microtome and stained with Hematoxylin Eosin (H \& E) from Merck. Finally, the histological structure and histopathological changes of gill, liver and muscles were investigated using a light microscope and recorded.

\section{RESULTS AND DISCUSSION}

\section{Heavy Metals Contents}

The results showed that the fish obtained from Payau River exhibited wide range of variations in metal levels. The levels of $\mathrm{Pb}$ and $\mathrm{Cd}$ were below 0.003 $\mathrm{mg} / \mathrm{kg}$ and $0.002 \mathrm{mg} / \mathrm{kg}$, respectively (Table 1). These levels were still in the range of the standard regulation. However, $\mathrm{Cu}$ and $\mathrm{Zn}$ levels have exceeded the maximum concentration allowed in quality standard. Metals concentration in the fish in this present study is higher compared to the previous study obtained by Suyatna et al., (2014). $\mathrm{Cu}$ accumulation in the spotted catfish from the previous study was $1.9 \mathrm{mg} / \mathrm{kg}$ and in this present study was $2.93 \mathrm{mg} / \mathrm{kg}$.
The effect of metals such as $\mathrm{Pb}, \mathrm{Cd}, \mathrm{Cu}$, and $\mathrm{Zn}$ in organisms may varies. One of them is the destruction of important organ tissues in the exposed organism. The concentration of $\mathrm{Cu}$ and $\mathrm{Zn}$ in the fish in the present study were high, namely 2.93 $\mathrm{mg} / \mathrm{kg}$ and $65.55 \mathrm{mg} / \mathrm{kg}$, respectively. Heavy metals are known to be easily accumulated in fish tissues because fish is a good accumulator (Sabullah et al., 2015). Copper is commonly consumed by fish for metabolism function. However. It becomes toxic if the fish is exposed to a higher concentration for longer period (Annabi et al., 2013). In a previous study conducted by Karayakar et al., (2010) in Padrilah et al., (2018) it was observed that copper was accumulated more in the liver of Anguilla compared to the gills and muscles. A similar observation was also obtained by Rajkowska and Protasowicki (2013) who claimed that copper was mostly accumulated in the fish liver compared to the other organ like kidney, digestive tract, spleen, gill and muscles.

Table 1. Metals $(\mathrm{Pb}, \mathrm{Cd}, \mathrm{Cu}$, and $\mathrm{Zn})$ concentrations in the freshwater fish obtained from Payau River

\begin{tabular}{lcccccccc}
\hline \multirow{2}{*}{ Sample } & \multicolumn{7}{c}{ Metals concentrations $(\mathrm{mg} / \mathrm{kg})$} \\
\cline { 2 - 9 } & $\mathrm{Pb}$ & $\mathrm{Pb}^{*}$ & $\mathrm{Cd}$ & $\mathrm{Cd}^{*}$ & $\mathrm{Cu}$ & $\mathrm{Cu}^{*)}$ & $\mathrm{Zn}$ & $\mathrm{Zn}^{*}$ \\
\hline Chanda sp & $<0.003$ & $<0.003$ & $<0.002$ & 1.01 & 2.63 & 1.9 & 65.51 & 89.54 \\
\hline $\begin{array}{l}\text { Micropogenias } \\
\text { undulates }\end{array}$ & $<0.003$ & $<0.003$ & $<0.002$ & - & 2.93 & - & 60.23 & - \\
\hline Kryptopterus $\mathrm{sp}$ & $<0.003$ & - & $<0.002$ & - & 2.65 & - & 64.21 & - \\
\hline Arius maculatus & $<0.003$ & $<0.003$ & $<0.002$ & 0.92 & 2.93 & & 65.55 & 86.49 \\
\hline $\begin{array}{l}\text { Quality } \\
\text { Standard }\end{array}$ & $0.3^{\mathrm{a})}$ & & $0.1^{\mathrm{a})}$ & & $0.02^{\mathrm{b})}$ & & $0.1^{\mathrm{b})}$ & \\
\hline a) National Standards Agency Indonesian Republic, SNI 7387. 2009. & & & \\
b) Qualty standard from Directorate of Drug and Food Control No.03725/B/SK/VII/89 \\
*) Results from Suyatna et al. (2014)
\end{tabular}

Zinc $(\mathrm{Zn})$ is an essential metal that in small concentration is very important for metabolism of coenzyme in organism. However, increasing exposure of $\mathrm{Zn}$ 
http://ijwem.ulm.ac.id/index.php/ijwem

concentration in the body of fish could be harmful for the fish. Metals, like $\mathrm{Cu}$ and $\mathrm{Zn}$ could be toxic if fish cannot tolerance certain level concentration and accumulating this material may harmful to human consumption.

\section{Histopathology of the Organs}

The histopathological alteration in the gills of varies fish obtained from sampling site are displayed in Figure 2. The Gills of Chanda sp have displayed haemorrhage and secondary lamellae disintegration (black arrow) (Figure 2a). The gills of Pseudociennas sp showed some hyperplasia of epithelial cells (blue arrow) (Figure 2b). Meanwhile, Kryptopterus
ISSN: 2477-5223 (Online)

cryptopterus and Arius maculatus suffered from oedema of lamellar secondary, haemorrhage and lamellar fusion (Figures $2 \mathrm{c}$ and $2 \mathrm{~d}$ ). Lamellar oedema is most frequent following exposure to chemical pollutants such heavy metals, pesticides and formalin over dosage.

Pathological changes in the gill of the fish could be regressive changes including epithelial oedema, necrotic pillar cells, haemorrhagic and telangiectasia and progressive changes are cell hypertrophy, fusion two secondary lamella, hyperplasia mucus cells and epithelial cells (Takashima and

Hibiya, 1995).

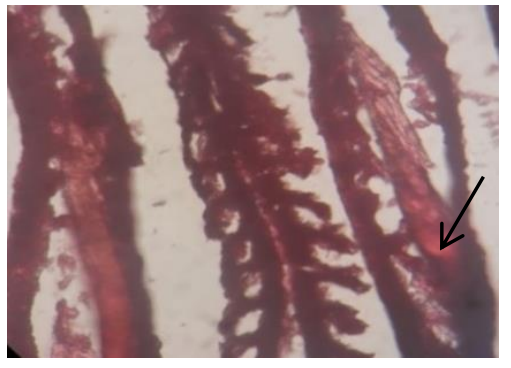

A: Chanda sp



$\mathrm{C}:$ Kryptopterus $\mathrm{sp}$

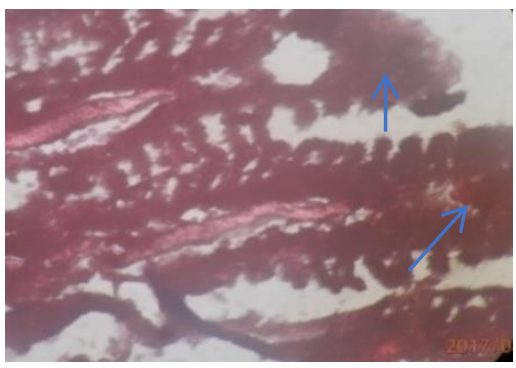

B: Pseudociennas sp



$\mathrm{D}$ : Arius sp

Figure 2. Gill of studied fishes (H+E, X 1000)

Hyperplasia of lamellar epithelium is generally due to an increase in numbers, and migration, of the Malpighian cells of the Journal of Wetlands Environmental Management

Vol 8, No 2 (2020) 149 - 157

http://dx.doi.org/10.20527/jwem.v8i2.217 primary lamella (Robert, 2012). Abnormal condition caused fusion of lamella, cartilaginous haemorrhagic was indicating 
that gill lamella has irritation witch harmfully substances in the waters as environmental life of fish. Gill is important organ for respiration and gas exchange. Their vulnerability is thus considerable because their external location and necessarily intimate contact with the water means that they are liable to damage by an irritant material, whether dissolved or suspended, in the water.

A study on the effect of heavy metals to the gills showed varies symptoms, among others hyperplasia, lamella lifting, fusion or oedema (Mohammed, et al., 2016) . This was also seen in the study conducted by Fernandez et al. (2007), which showed the gills of Nile tilapia had experienced epithelium lamella lifting, epithelium proliferation, filament oedema and fusion of lamella. High level of $\mathrm{Cu}$ in the fish in the present study is expected to cause alterations in the organ's tissues, although the damage of tissues is different depend on sensitivity of species to the toxic substance. The gill is the first organ to accumulate heavy metals at a level higher than the concentration deemed toxic through absorption along the gill surface and gut wall (Annabi et al., 2013).

All of the livers in the fish samples showed cloudy swelling (black arrow). There were congestion and degenerative in the liver of Chanda sp, and some debris were spotted in the hepatocyte and haemorrhagic of the tissues (Figure 3a.); Figure 3b.displays congestion and vacuolar degeneration in the liver of Pseudociennas sp. ; Figure 3c shows necrosis of hepatocyte in the sinusoid (brown arrow), cloudy swelling (black arrow), and congestion (blue arrow) in the liver of Kryptopterus sp. While Figure 3d. displays liver inflammation and fatty degeneration of Arius sp, and some debris are also appeared.
Histopathology result of this study showed that liver of Chanda $s p$ experienced congestion and degenerative, and some debris were identified in the hepatocyte and haemorrhagic of tissues. The liver of Pseudociennas sp. showed congestion and vacuolisation. The liver of Kryptopterus sp. experienced necrosis of hepatocyte in the sinusoid (brown arrow) and congestion (blue arrow). Meanwhile, the liver of Arius sp. showed inflammation of tissues.

Inflammation occurs as is the basic protective response to tissue damage of whatever cause and is common to all vertebrates (Robert, 2012). The most common cause of such damage are microbes and their excretory product (toxin), physical and their chemical trauma. Hepatic tissues has many important physiological function including the intermediate metabolism of protein, carbohydrate and lipid, the synthesis of plasma protein such as albumen, and the important reproductive protein oval albumen, and also the formation and secretion of bile. A wide range of causes can damage the liver, and because of the liver's multiple metabolic function, such damage can have serious effects on the metabolism of the entire animal. Necrotic hepatocytes (focal necrosis) may be associated with a variety of toxic condition including of toxic heavy metal. Heavy metals are hepatotoxican (target organ of the liver), neurotoxican (attacks the nervous system), and also nephrotoxican (attacks the kidneys) and then accumulate in the SH group (sulfidril) and interfere with the work of enzymes (Patricia, 2000).

The form of liver alteration of Pseudociennas sp was cloudy swelling and vacuolisation hepatocyte. Due to the existence of interference from the environment causes 


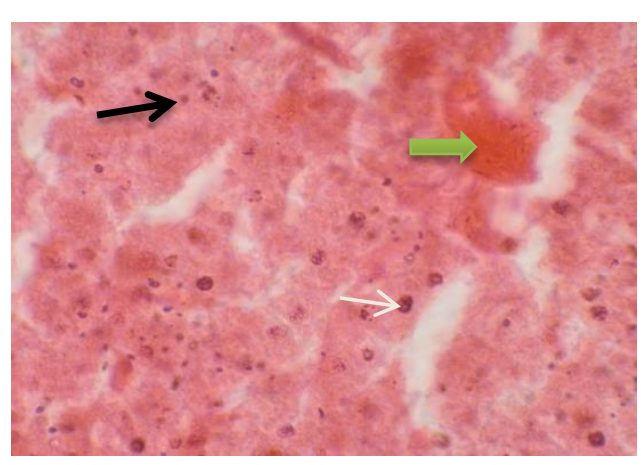

A: Glass fish (Chanda sp). haemorrhagic , pyknotic and cloudy swelling

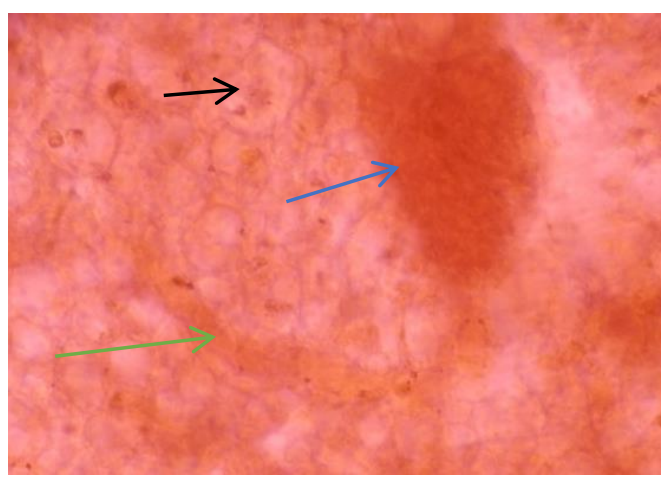

C: Lais ( Kryptopterus sp). Congestion, cloudy swelling and necrosis

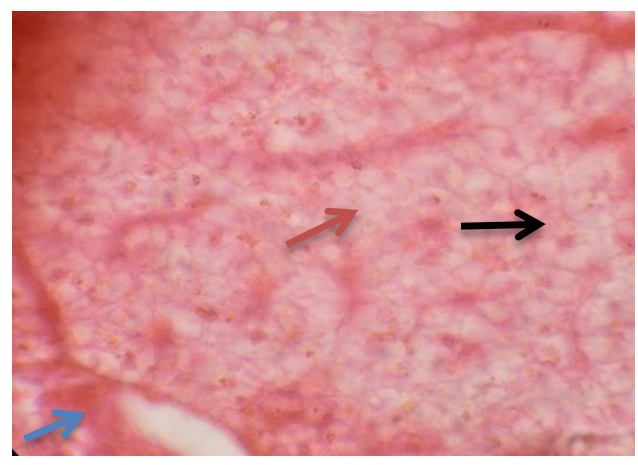

B: Croaker (Pseudociennas sp). Cloudy swelling and vacuolisation hepatocyte

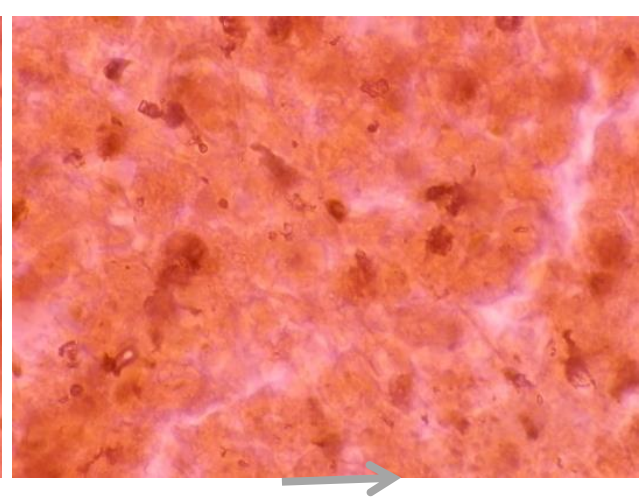

D: Spotted catfish (Arius sp). Liver inflammation, fatty degeneration (green arrow)

Figure 3. Histopathology results of fishes' studied (H + E, X 1000).

cells to be abnormal in size, other than that the cells become swollen. This condition causes pressure on the cell membrane, so that the cell can break out the cell nucleus and the cell will die, glycogen out of the cell and the tissue looks foggy (cloudy).

Some histological changes were observed in the liver of Kryptopterus sp. The changes were necrosis of hepatocyte in sinusoid, cloudy swelling, and congestion. While the liver of Arius sp. showed inflammation and fatty degeneration. Liver is an organ that can carry out xenobiotic detoxification that enters the body of the organism. The liver has metabolizing enzymes, which when working can be the surrounding cells, including the liver cells themselves to become die. (Patricia, 2000). Therefore, if the liver continues to receive pressure from harmful chemicals and exceed its physiological ability, the liver will experience thickening of liver cells (cirrhosis).

Histopathological changes are indicative of fish experiencing environmental stress in the form of pollutants, one of which is heavy metals as detected in the fish's body and then there are a figure of muscles of the sampled of fish. Figure $4 \mathrm{a}$ shows fiber splitting of the 
muscle of Chanda sp.; Figure 4b displays accumulation of debris and myofibril damage of the muscle of Pseudociennas sp ; Figure $4 \mathrm{c}$ shows normal sarcolemma (black arrow) and myotome fibrosis (blue arrow) of Kryptopterus sp; and Figure 4d shows myotome haemorrhagic in the muscle of Arius sp. All muscles experienced damage, yet not all the conditions are extreme. However, this phenomenon could be an indication of the presence of pollutants that have been accumulated in aquatic biota.

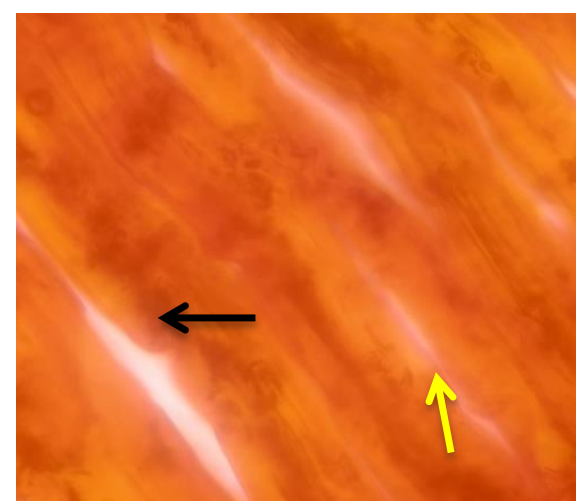

A: Chanda sp. Fibre splitting

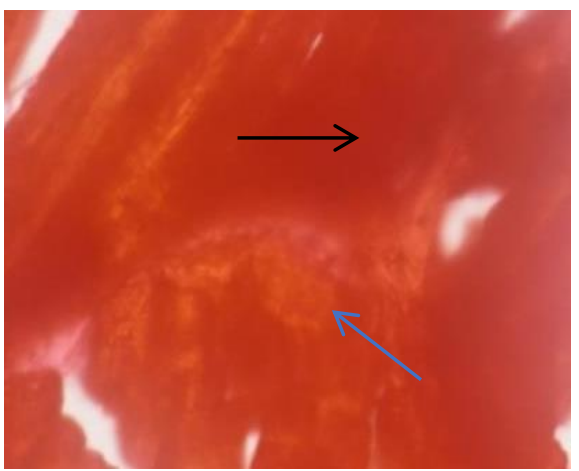

C: Kryptopterus sp. Myotome fibrosis

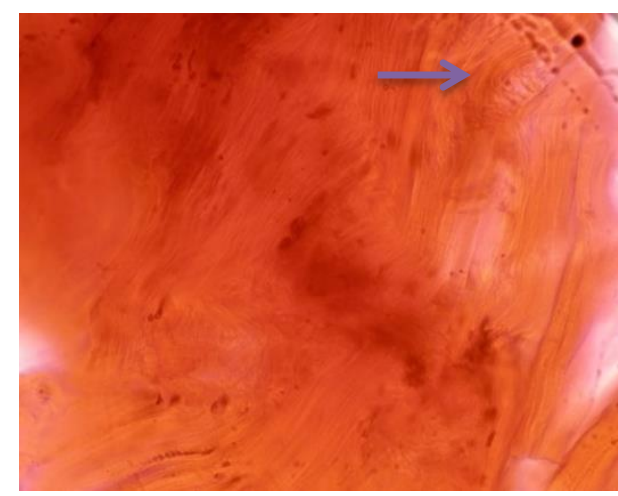

B: Pseudociennas sp.

Accumulation of debris

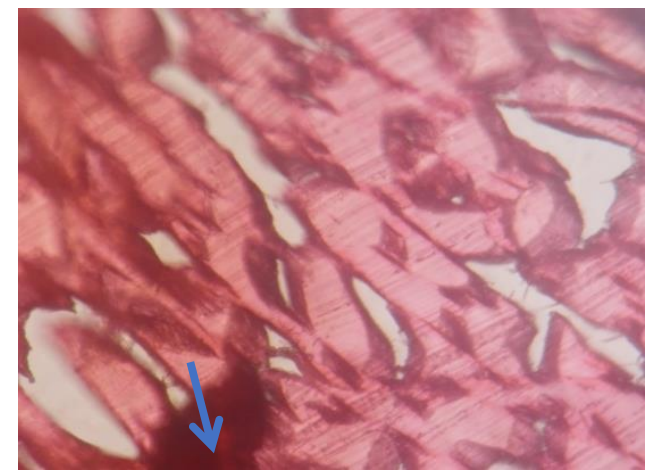

D: Arius sp. Hemorrhagic

Figure 4. Histopathological changes in fishes studied ( H+E, X 1000)

The black arrow indicates the accumulation of chemicals and meat fibers degenerating. The condition of fish is not healthy and is not safe for consumption, considering the high content of $\mathrm{Cu}$ and $\mathrm{Zn}$ in the body of the fish. This is as state by Heidel \& Smith (2007) that many fish look healthy but are sick fish. Fish remain alive

Journal of Wetlands Environmental Management

Vol 8, No 2 (2020) 149 - 157

http://dx.doi.org/10.20527/jwem.v8i2.217 and active, but store or accumulate pathogens or other harmful agents in their tissues.

\section{CONCLUSIONS}

The levels of $\mathrm{Pb}$ and $\mathrm{Cd}$ in the fish were still fulfil the food safety Quality Standards, yet $\mathrm{Cu}$ and $\mathrm{Zn}$ have exceeded the permitted Quality 
Standards for food safety. The tissues and cells of the gills, liver and muscles (meat) have exhibited some changes including hyperplasia, necrosis, congestion, cloudy swelling, fatty degeneration and inflammation, indicating the fish suffered from environmental disturbances.

\section{ACKNOWLEDGMENTS}

Authors acknowledge financial support from Faculty of Fisheries and Marine Science, Laboratory of Water Quality, Laboratory of Aquatic Toxicology for allowing us to used laboratory facilities.

\section{REFERENCES}

Annabi, A.,Said, K \& Messaori, I. 2013. Cadmium: Bioaccumulation, histopathology and detoxifying mechanisms in fish. American Journal of Research Communication, 4, 60-79.

Authman, M. M. (2015). Use of Fish as Bioindicator of the Effects of Heavy Metals Pollution. Journal of Aquaculture Research \& Development, 6. https://doi.org/10.4172/2155-9546.1000328

Mohammed S. Y, Omer F. I, Sabahelkhier M.K, Abd El-Halim, M. I. (2016). Effect of Some Heavy Metal on Histological Structural of Gills and Liver of Rabbit Fish (Siganus rivulatus) from Two Sites Along Red Sea Coast, SUDAN. International Journal of Advanced Research, 4,1040-1050. https://doi.org/10.21474/IJAR01.

Baker J.T.P. 1969. Histological and electron microscopical observations on copper poisoning in the winter flounder (Pseudopleuronectes americanus). J. Fish. Res. Bd. Can. 26, 2785-2793.

Boudou, A., D.G Scauld \& I.D. Desmazes. 1983. Ecotoxicological role of the membrane barrier's in Transport and Bioaccumulation of Mercury compound in J.ONriagu (ed). Aquatic Toxicology, Wiley
Interscience Publication, John Wiley and Sons, New York.

Directorate Generale of Drug and Food Control Indonesian Republic. 1989. Maximum level pollutants of metals in food consumption.

Fernandes, 2007. Histopathological Changes in Liver and Gill epithelium of Nile tilapia (Oreochromis niloticus) exposed to Waterborne Copper. Depto Engeharia Biological.

Heidel, J. and C. Smith. 2007. General Histopathology and Neoplasia. Fish Histology manual.

Indonesian National Standards Agency. 2009. SNI 7387-2009. Maximum Level pollutants of Heavy metal in Food.

Kock, G, Triedl M \& Hofer. R. 1996. Seasonal Pattern of Metal Accumulation In Arctic char (Salvelinus alpinus) from an oligotrophic Alpine lake relate to temperature. Can. J.Fish. Aqat. Sci. 53, 780-786.

Morison, J. 2007. Normal Histology. Fish Histology manual.

Munford, S. 2007. Submitting samples and Tissue Processing. Fish Histology and Histopathology.

Osman, A.G.M., Reheem, A.E., Baset, M.A.E., AbuellFadly, K.Y \& Rab, A.G.G. 2010. Enzymatic and histopathologic biomarkers as indicators of aquatic pollution in fish. Natural Science, 2, 1302-1311

Padrilah, S.N., M.K Sabullah., M.Y.A Sukhor., N. Adeela Y.N.A. Shamaan and S. Aqlima Ahmad. 2018. Toxicity Effects of Fish Histopathology on Copper Accumulation. Pertanika J. Trop. Agric. Sci. 41, 519 - 540

Patricia, E.Levi., Ernest Hodgson. 2000. A Texbook of Modern Toxicology. North Carolina State University.

Pelgrom, S., Lamers, L., Lock, R. Balm. P and Wendelaar Bonga s. 1995. Integrated Physiological Response of Tilapia Oreochromis mosambicus, to sublethal Copper Exposure. Aquatic. Toxicol. Sci.42, $630-648$.

Rajkowska, M and Protasowicki,M. 2013. Distribution of metals (Fe, Mn, $\mathrm{Zn}, \mathrm{Cu}$ ) in fish tissues in two lakes of different trophic 
in Northwestern. Polland. Environmental monitoring and Assesment, 185 (4), 3493 3502.

Robert, R.j. 2012. Fish Pathology, $4^{\text {th }}$ ed. Bailierre Tindall.

Rocha \& Monteiro RAF. 1999. Histology and Cytology of Fish Liver. Areview, p 321-344 In: Saksena DN (ed) Ichthyology. Recent Research Advances Science Publisher, Takashima dan Hibiya. 1995. An Atlas of Fish Enfield, New Hampshire.

Sabullah, M.K.,Ahmad, S.A., Shukor, WHO. 1998. Copper Environmental Health M.Y.,Gansau. A.J. Syed., M.A., Sulaiman. M.R \& Shamaan, N.A. 2015. Heavy metals biomarker. Fish behaviour cellular alteration, enzymatic reaction and proteomic approaches. International Food Research Journal, 22, 435 - 454.

Suyatna. I, Sulistyawati, Adnan, Ghitarina, M. Sahrir, Abdunnur and Sahrul. 2017. Heavy metal level in water and fish samples from coastal waters of Mahakam Delta, Kutai Kartanegara District, East Kalimantan, Indonesia. AACL.Bioflux, 10. Histology. Kodansha Ltd. Tokyo Criteria 200. IPCS- International Program on Chemical Safety. World Health Organization, Geneva. 